\begin{tabular}{|c|c|c|}
\hline \hline \hline & International Journal of Current Research in & \\
\hline & Biosciences and Plant Biology & \\
\hline ISSCELLENT & ISS : 2349-8080 (Online) $\bullet$ Volume $3 \bullet$ Number 10 (October-2016) \\
\hline \hline
\end{tabular}

\title{
Evaluation of Performance Diversity among Four Determinate Tomato (Lycopersicon esculentum Mill.) Varieties Grown under High Tunnel in Iwollo, South Eastern Nigeria
}

\author{
P. O. Ugwuanyi ${ }^{*}$, O. G. Nwankwo', J. O. Adinde ${ }^{2}$, U. J. Anieke ${ }^{1}$, C. M. Ukwuani ${ }^{3}$ and \\ A. C. Aniakor4
}

${ }^{1}$ Department of General Studies, Enugu State Polytechnic, Iwollo, Enugu State, Nigeria

2Department of Horticultural Technology, Enugu State Polytechnic, Iwollo, Enugu State, Nigeria

3 Department of Fishery Technology, Enugu State Polytechnic, Iwollo, Enugu State, Nigeria

${ }^{4}$ Department of Agricultural Technology, Enugu State Polytechnic, Iwollo, Enugu State, Nigeria

*Corresponding author.

\begin{abstract}
A b st r a ct
An experiment was conducted at the Research and Demonstration farm of Enugu State Polytechnic, Iwollo to evaluate the performance of four determinate tomato (Lycopersicon esculentum Mill.) varieties grown under high tunnel. Four tomato varieties viz., Supremo hybrid, BHN-1021, Roma VF and Iwollo local constituted the treatments. The experiment was laid out in completely randomized design (CRD) with three replications. Data were collected on plant height, number of leaves per plant, number of branches per plant, days to 50\% flowering, disease severity, number of fruits per plant, weight of a fresh fruit and fresh fruit weight per plant. The data collected were analysed using analysis of variance (ANOVA) and treatment means separated using least significant difference (LSD) at 0.05 level of probability. The result revealed significant difference $(p<0.05)$ in plant height, number of branches per plant, number of leaves per plant, number of fruit per plant, weight of a fresh fruit and fresh fruit weight per plant among the tomato varieties with Supremo hybrid variety having superior value in terms overall performance. It could be concluded that Supremo hybrid tomato variety is best suited for cultivation under high tunnel. It is therefore recommended for high tunnel production of tomato in Iwollo.
\end{abstract}

\author{
Article Info \\ Accepted: 13 September 2016 \\ Available Online: 06 October 2016
}

\begin{tabular}{l} 
K e y w o r d s \\
\hline Determinate \\
High tunnel \\
Lycopersicon esculentum \\
Tomato varieties
\end{tabular}

Ke ywords

High tunnel

Tomato varieties

\section{Introduction}

Tomato (Lycopersicon esculentum Mill.) is one of the most highly praised vegetable crops consumed extensively. It belongs to Solanaceae family. Its origin is the Andean zone particularly Peru-Ecuador-Bolivian areas (Salunkhe et al., 1987) but cultivated tomato originated in Mexico. As a relatively short duration crop that gives high yield, it is economically attractive and the area under cultivation is increasing daily (Zahedi et al., 2012). It ranks second following potato in terms of area cultivated, but first as a processing crop (Enujeke, 2013; Alawathugoda and Dehanayake, 2014).

Tomatoes are commonly classified as determinate or indeterminate. Determinate or bush types bear a full crop all at once and top off at a specific height; they are often good choices for container growing. Determinate types 
are preferred by commercial growers who wish to harvest a whole field at one time, or home growers interested in canning. Indeterminate varieties develop into vines that never top off and continue producing until killed by frost. They are preferred by home growers and local-market farmers who want ripe fruit throughout the season. As a palatable and succulent crop, tomato is used in many types of dishes. In Nigeria, tomato is regarded as one of the most important vegetables. It is widely employed in cannery and made into soups, sauces, juices etc. It is used in the preparation of pasta, salads, snacks, sandwich and cocktails. Tomato is rich in minerals, vitamins, essential amino acids, sugars and dietary fibers. One medium sized tomato provides $40 \%$ of the recommended daily allowance (RDA) of vitamin C (ascorbic acid), 20\% of the RDA of vitamin A, substantial amounts of potassium, dietary fiber, calcium, and lesser amounts of iron, magnesium, thiamine, riboflavin, and niacin, yet contains only about 35 calories (FAO, 1979). Vitamins A and B complex in tomato help to prevent eye and skin diseases. Potassium is helpful in controlling the rate of heart beat, heart diseases and stroke (Enujeke, 2013). Giovannucci (1999) reviewed a number of epidemiological studies and concluded that the intake of tomato products is associated with a lower risk of a variety of cancers. The main antioxidants in tomatoes are carotenoids, ascorbic acid and phenolic compounds (Giovanelli et al., 1999).

Inspite of numerous use of tomato, production in Nigeria are not enough for local demands (Olaniyi et al., 2010). The low yield obtained in Nigeria especially in southeastern Nigeria has been attributed to several factors including high temperatures, high humidity, excessive rainfall (Opena et al., 1989), diseases and insect pests (Ma, 1985), lack of appropriate varieties and unsuitable cultural practices (Žnidarčič et al., 2003). The yield of tomato and quality depends on numerous factors including genotype and environmental conditions. Among these factors, it is the suitability of tomato variety to the growing condition the most determinant factor for growth, yield and fruit quality of tomato. Majambu et al. (1996) and Sajjan et al. (2002) reported that growth characters of crops such as plant height, leaf area, number of leaves or branches and fruit yields were influenced by genetic factors of different varieties. Ibrahim et al. (2000) reported that the differences in growth indices of crop varieties are normally influenced by both their genetic constitution and environmental factors. Tan (2006) indicated that available genetic material in tomato varieties allows discrimination of external and internal quality attributes that must satisfy consumer requirements and indulgences. Three factors drive consumers' preference: physical appearance (colour, size, shape, defects, and decay), firmness and flavour (Nzanza, 2006). There is large variation in Vitamin $\mathrm{C}$ levels among tomato cultivars (Leonardi et al., 2000). The types of antioxidants present in tomato are also used to differentiate tomato cultivars (Langlois et al., 1996; George et al., 2004). The overall antioxidant activity of tomatoes varies considerably according to the genetic variety, ripening stage and growing conditions (Davies and Hobson, 1981; Leonardi et al., 2000). Breeding over the past years has substantially changed the tomato plant and its fruit characteristics. Tomato varieties available today have a wide range of plant characteristics (Benton, 2008). They are specifically adapted to a particular set of growing conditions, such as high tropical temperatures, field and greenhouse conditions.

High tunnel is a greenhouse- like structure whereby plants are grown utilizing the soil (Wells and Loy, 1993). They are considered to be a less expensive alternative to a true greenhouse and yet can provide some control of environmental factors such as wind, rain, and some insects and diseases. High tunnel also extends the growing season, increase opportunities for colour development, and can improve fruit quality. High value warm-season crops such as pepper and tomato have been successfully grown under high tunnel (Wells and Loy, 1993; Wittwer and Castilla, 1995). Mesbah et al. (2014) reported varied performance of some tomato varieties grown under high tunnel conditions.

The decision about what tomato cultivar to grow is perhaps more complex than for other crops (Schonbeck et al., 2006). This is because of the different growth habits, time to maturity, size, shape, colour, flavour, disease resistances, fruit yield potential and quality, and tolerance to physiological disorders and abiotic stresses. Presently, large numbers of local and imported tomato varieties including hybrids are available in the market, and seeds of these varieties are sold at exorbitant prices. Tomato growers use these varieties without knowing their performance under various growing conditions. At present, no variety of tomato has been identified as most suitable for high tunnel production in Iwollo, Southeastern, Nigeria. The study was therefore aimed to evaluate the performance of four determinate tomato varieties viz., Supremo hybrid, BHN-1021, Roma VF and Iwollo local, in a way to determine what cultivar is best suited for high tunnel production in Iwollo, southeastern Nigeria. 


\section{Materials and methods}

\section{The research site}

The research was conducted at the Teaching and Research farm of the Department of Agricultural Technology, Enugu State Polytechnic, Iwollo. It is located within Latitude $06^{\circ} 16.834^{\prime} \mathrm{N}$ and longitude $007^{0}$ $16.834 \mathrm{E}$ (Maplandia, 2016). The annual rainfall is between April and November with short break in August.

\section{Nursery preparation}

The tomato varieties were raised in the nursery medium that was prepared at the ratio of 3:2:1 of top soil, poultry manure and river sand respectively. The nursery was shaded to protect the seedlings from harsh weather condition. The seedlings were watered as required.

\section{High tunnel construction}

A high tunnel of $7 \mathrm{~m}$ (height) by $5 \mathrm{~m}$ (width) by 9 (length) was constructed using bamboo sticks. The high tunnel was covered with a blue polyethylene film.

\section{Experimental design and treatments}

The experiment was laid out in completely randomized design (CRD) with three replications. The treatment comprised four determinate tomato varieties - two hybrid varieties (Supremo and BHN-1021), one improved variety (Roma VF) and one local variety (Iwollo local). The treatments were randomly assigned to the experimental design. The varieties were transplanted into wooden boxes of $0.25 \mathrm{~m}$ high, $1.5 \mathrm{~m}$ long and $0.5 \mathrm{~m}$ wide each containing $50 \mathrm{~kg}$ of top soil.

\section{Horticultural practices}

Normal horticultural practices were carried out throughout the experiment as at when due. Healthy seedlings from the nursery were transplanted into each wooden box four weeks after sowing in a single row using a spacing of $50 \mathrm{~cm}$ between plants. Poultry droppings at the rate of 15 tons per hectare were incorporated into the soil two weeks before transplanting. Carbofuran $(5 \mathrm{G})$ at the rate of $3 \mathrm{~kg}$ per hectare was also incorporated into the soil one week before transplanting to control nematode disease. Knockoff insecticide (Lambda cyhalothrin) was used to control insect pest while Teem fungicide (Cabendazem and Mancozeb) was used to control fungal diseases.

\section{Data collection}

Data were collected on plant height, number of leaves per plant, number of branches per plant, days to $50 \%$ flowering, disease severity, number of fruits per plant, weight of a fresh fruit and fresh fruit weight per plant.

\section{Plant height (cm)}

Data on plant height was collected from two tagged sample plants in each box. This was determined using a measuring tape to measure from the base of the plant to the top of the plant at 60 days after transplanting (60DAT).

\section{Number of leaves per plant}

Data on number of leaves per plant was collected from two tagged sample plants in each box. This was determined by direct counting of the leaves at 60DAT.

\section{Number of branches per plant}

Data on number of branches per plant was collected from two tagged sample plants in each box. This was determined by direct counting of the branches at 60DAT.

\section{Days to 50\% flowering}

This was determined by counting the number of days it took half of the plants to flower from the time of transplanting.

\section{Disease severity}

All the four stands in each box were used to determine disease severity at 60DAT. Disease severity (\%) was determined by total number of infected leaves over total number of leaves multiplied by $100(\%)$ as described by Chaube and Pundhir (2005).

Disease severity $=\frac{\text { Number of diseased leaves }}{\text { Total number of leaves }} \times 100$

Disease severity was scored on a 5 point scale $(0-4$ scale) as described by Omeje et al. (2016) as given in Table 1 . 
Table 1. Disease severity score.

\begin{tabular}{lll}
\hline Scales & $\begin{array}{l}\text { Severity Score range } \\
(\boldsymbol{\%})\end{array}$ & Description \\
\hline 0 & $<1$ & No infection \\
1 & $1-25$ & Low infection \\
2 & $26-50$ & Moderate infection \\
3 & $51-75$ & High infection \\
4 & $>75$ & Very high infection \\
\hline
\end{tabular}

\section{Number of fruits per plant}

Number of fruits per plant was counted from two sample plants upon harvesting at breaker stage.

\section{Weight of a single fresh fruit (g)}

The weight of a single fresh fruit was determined on an electronic scale. Ten (10) fruits from the sample plants were used to determine weight of a single fresh fruit. The average of the ten fruits was taken as the weight of a single fresh fruit.

$$
\text { Weight of a fresh fruit }(\mathrm{g})=\frac{\text { Total weight of fresh fruits weighed }}{\text { Total number of fresh fruits weighed }}
$$

That is, weight of a fresh fruit $(g)=\frac{X(g)}{10}$

\section{Fresh fruit weight per plant (kg)}

Fresh fruit weight per plant was calculated using number of fruit per plant and weight of a fresh fruit weight. Fresh fruit weight per plant was determined by multiplying the weight of a fresh fruit ( $\mathrm{g}$ ) by the number of fresh fruit per plant and dividing by 1000 to convert to kilogram $(\mathrm{kg})$.

Thus,

Fresh fruit wt. per plant $(\mathrm{kg})=\frac{[\mathrm{X}(\mathrm{g}) / 10 \times \text { No. of fresh fruits per plant }]}{]}$

1000

\section{Statistical analysis}

Data obtained were subjected to analysis of variance (ANOVA) using Genstat Release 10.3DE software (GenStat, 2011). Separation of treatment means was done using least significant difference as outlined by Obi (2002).

\section{Results}

\section{Pre-planting soil characteristics}

The soil used for the experiment was found to belong to sandy loam textural class. The nutrient status was found to comprise nitrogen $\left(0.018 \mathrm{~g} \mathrm{~kg}^{-1}\right)$, phosphorus $(21.45$ $\mathrm{ppm})$, organic matter $\left(2.40 \mathrm{~g} \mathrm{~kg}^{-1}\right)$, magnesium $(2.58$ meq/100g), calcuim (2.86 meq/100g), potassium (0.32 meq $/ 100 \mathrm{~g})$, sodium $(2.84 \mathrm{meq} / 100 \mathrm{~g})$ and with $\mathrm{pH}$ value of 5.8 as shown in Table 2 .

Table 2. Pre-planting physico-chemical properties of the soil.

\begin{tabular}{ll}
\hline Soil Properties & Values \\
\hline Physical Properties (\%) & \\
Silt & 16.68 \\
Clay & 20.52 \\
Sand & 62.80 \\
Textural class & Sandy loam \\
Chemical Properties & \\
Phosphorus $(\mathrm{ppm})$ & 21.45 \\
Organic carbon $\left(\mathrm{g} \mathrm{kg}^{-1}\right)$ & 2.40 \\
Soil pH $\left(\mathrm{H}_{2} \mathrm{O}\right) /(\mathrm{KCl})$ & $5.8 / 5.2$ \\
Nitrogen $\left(\mathrm{g} \mathrm{kg}^{-1}\right)$ & 0.018 \\
Exchangeable cations (meq/100g soil) & \\
Magnesium & 2.58 \\
Calcium & 2.86 \\
Potassium & 0.32 \\
Sodium & 2.84 \\
\hline
\end{tabular}

\section{Growth and disease resistance of four tomato} varieties

The plant heights of the four tomato varieties (Supremo, BHN-102, Roma VF and Iwollo local) are shown in Table 3. There was significant difference $(p<0.05)$ in plant height among the tomato varieties. BHN-1021 variety had the highest plant height $(76.17 \mathrm{~cm})$, while Roma VF had the least $(54.55 \mathrm{~cm})$ in this order; BHN1021 $>$ Supremo>Iwollo local $>$ Roma VF. However, heights of Supremo $(66.67 \mathrm{~cm})$ and Iwollo local $(63.5 \mathrm{~cm})$ varieties are statistically the same. Consequently, the number of leaves per plant and the number of branches per plant differed significantly $(p<0.05)$ among the four varieties and followed the same trend. The highest number of branches per plant (8.83) and the highest number of leaves per plant (58.33) were recorded in Roma VF while the least (5.33 and 35 respectively) was obtained in BHN-1021 variety. The number of branches and leaves of Iwollo local (7.33 and 49.5 respectively) were statistically at par with that of 
Supremo variety (7.17 and 48.03 respectively). Days to $50 \%$ percent flowering and disease severity as presented in Table 3 showed no significant differences $(p>0.05)$ among the four varieties.

Table 3. Growth parameters and disease severity of four tomato varieties.

\begin{tabular}{llllll}
\hline Tomato varieties & Plant height $(\mathbf{c m})$ & $\begin{array}{l}\text { No. of branches per } \\
\text { plant }\end{array}$ & $\begin{array}{l}\text { No. of leaves per } \\
\text { plant }\end{array}$ & $\begin{array}{l}\text { Days to 50\% } \\
\text { flowering }\end{array}$ & $\begin{array}{l}\text { Disease } \\
\text { severity }\end{array}$ \\
\hline Supremo & $66.67^{\mathrm{b}}$ & $7.17^{\mathrm{b}}$ & $48.03^{\mathrm{b}}$ & 44.67 & 2.33 \\
BHN-1021 & $76.17^{\mathrm{a}}$ & $5.33^{\mathrm{c}}$ & $35.00^{\mathrm{c}}$ & 43.67 & 2.00 \\
Roma VF & $54.55^{\mathrm{c}}$ & $8.83^{\mathrm{a}}$ & $58.33^{\mathrm{a}}$ & 45.67 & 1.33 \\
Iwollo local & $63.50^{\mathrm{b}}$ & $7.33^{\mathrm{b}}$ & $49.50^{\mathrm{b}}$ & 41.00 & 1.33 \\
LSD 0.05 & 4.301 & 0.719 & 5.108 & 3.279 & \\
S.E. & 2.284 & 0.382 & 2.713 & 7.5 & 0.5 \\
CV $(\%)$ & 3.5 & 5.3 & 5.7 & 28.6 \\
\hline
\end{tabular}

LSD = Least significant difference; NS= Non significant; S. E. = Standard error; CV = Coefficient of variation. Mean values within the same column with the same letter are not significantly different $(p>0.05)$.

\section{Yield of four tomato varieties}

The results of number of fruits per plant, weight of a fresh fruit $(\mathrm{g})$ and fresh fruit weight per plant $(\mathrm{kg})$ of the four tomato varieties (Supremo, BHN-1021, Roma VF and Iwollo local) were presented in Table 4. There was significant difference $(p<0.05)$ among the tomato varieties in all the yield parameters evaluated. The highest number of fruit (14.83) was obtained in Roma VF while the least (8.17) was obtained in BHN-1021 variety. Number of fruits per plant (14.83) harvested from Roma VF was statistically at par with 14.67 fruits harvested from Iwollo local variety. Similarly, number of fruits per plant (8.33) harvested from Supremo was statistically at par with 8.17 fruits harvested from BHN1021 variety. Weight of a fresh fruit and fresh fruit weight per plant followed the same trend. The highest weight of a fresh fruit and fresh fruit weight per plant (119.86g and $0.997 \mathrm{~kg}$ respectively) were obtained in Supremo variety while the least $(40.7 \mathrm{~g}$ and $0.58 \mathrm{~kg}$ respectively) was obtained Iwollo local. The order was: Supremo $>$ BHN-1021 > Roma VF $>$ Iwollo local.

Table 4. Yield parameters of four tomato varieties.

\begin{tabular}{llll}
\hline Tomato varieties & No. of fruit per plant & Weight of a fresh fruit $(\mathbf{g})$ & $\begin{array}{l}\text { Fresh fruit weight per plant } \\
(\mathbf{k g})\end{array}$ \\
\hline Supremo & $8.33^{\mathrm{b}}$ & $119.86^{\mathrm{a}}$ & $0.997^{\mathrm{a}}$ \\
BHN-1021 & $8.17^{\mathrm{b}}$ & $102.5^{\mathrm{b}}$ & $0.84^{\mathrm{b}}$ \\
Roma VF & $14.83^{\mathrm{a}}$ & $50.74^{\mathrm{c}}$ & $0.75^{\mathrm{c}}$ \\
Iwollo local & $14.67^{\mathrm{a}}$ & $40.07^{\mathrm{d}}$ & $0.58^{\mathrm{d}}$ \\
$L S D_{0.05}$ & 2.506 & 5.365 & 0.0828 \\
$S . E$. & 1.331 & 2.849 & 0.0440 \\
$C V(\%)$ & 11.6 & 3.6 & 5.6 \\
\hline
\end{tabular}

LSD = Least significant difference; S. E. = Standard error; CV = Coefficient of variation. Mean values within the same column with the same letter are not significantly different $(p>0.05)$.

\section{Discussion}

The results presented in Table 3 and Table 4 showed that significant variability existed in plant height, number of leaves per plant, number of branches per plant, number of fruits per plant, weight of a fresh fruit and fresh fruit weight per plant among the four tomato varieties (Supremo, BHN-1021, Roma VF and Iwollo local) assessed. No significant variability existed in days to $50 \%$ flowering and in disease severity among the four varieties. Variability in vegetative growth of tomato varieties could be attributed to differences in genetic constitution with respect to growth rate and suitability of the growing conditions for the variety. This is in agreement with the findings of Majambu et al. (1996), Ibrahim et al. (2000), Sajjan et al. (2002) and Enujeke and Emuh (2015) who reported that genetic constitution of crop varieties influences growth characters which they express. Growth is a net result of various interactions like soil properties, soil fertility and type, climatic factors of rainfall and temperature stress, cultural practices (time of planting, weeding, tillage and disease control) and genetic constitution of the cultivar (Channapagouder et al., 2008). Haque et al. (1998) found maximum (116.6 $\mathrm{cm})$ and minimum $(47.6 \mathrm{~cm})$ plants heights during evaluation of tomato lines. Plant height differed among 
varieties of tomato due to the variation of varieties (Kallo et al., 1998; Manoj and Ragav, 1998; Olaniyi et al., 2010). Tallness, shortness and other morphological differences are varietal characteristics, which are controlled and expressed by certain genes (Fayaz et al., 2007). The highest plant height observed in BHN-1021 variety over other varieties could be attributed to an inherent ability to exhibit more apical dominance of auxin over the other varieties. The number of branches and leaves were least in the tallest variety (BHN-1021) and highest in the shortest variety (Roma VF). Reduced effect of auxin as may be in the shorter varieties probably reduced the inhibitory effect on cytokinin which in turn initiated more branches. Campbell et al. (2008) and Adinde et al. (2016) reported that reduced activity of auxin reduces the inhibitory effect on cytokinin which is responsible for development of lateral branches. More number of leaves obtained in shorter varieties possibly was an induction of more number of branches.

The local variety, Iwollo local was earlier than all the other varieties and took the least number of days to 50 percent flowering, followed by BHN-1021, Supremo and Roma VF however, there was no significant difference among the varieties. Narrow range was observed in the number of days to 50 percent flowering for the varieties. This probably was a confirmation that the varieties were all determinate tomatoes with short life span.

There was no significant difference among the four varieties in disease severity as shown in Table 3 . The tomato varieties probably had similar disease resistance potential. The disease severity of the varieties ranged from low to moderate. This could be an indication of high disease resistance in the four varieties evaluated. It has been reported that host genetic resistance is the most effective method of managing diseases of tomato (Yu et al. 1995; Blancard 1997). Development of disease resistant tomato genotypes has been reported to be the most efficient and environmentally friendly way to control disease when sufficient genetic variation for resistance is available (Hulbert et al. 2001).

Results obtained in number of fruits per plant, weight of a fresh fruit and fresh fruit weight per plant (Table 4) were in agreement with the findings of Barman et al. (1995), Mohanty (2002), Joshi et al. (2004), Singh and Raj (2004), Naika et al. (2005), Bok et al. (2006) and Haydar et al. (2007). In number of fruit per plant, higher values were obtained in Roma VF and Iwollo local varieties compared to Supremo and BHN-1021 varieties.
This may be attributed to higher number of flowers that successfully developed into more fruits possibly because of better genetic constitution and favourable conditions. The significant higher number of fruits in Roma VF and Iwollo local varieties was probably as a result of more number of branches per plant which possibly initiated more flower buds that resulted to more fruits.

Weight of a fresh fruit was significantly influenced by varietal differences. It did not follow the same superiority order with number of fruits per plant. Maximum weight of a fresh fruit was recorded in Supremo variety while the minimum was recorded in Iwollo local variety (Table 4). The wide variation among the varieties in respect to weight of a fresh fruit could be due to different varietal characteristics. Varietal influence on individual fruit weight was also reported by Meher et al. (1994). High weight of a fresh fruit is an indication of large fruit size. Varieties with large fruit size such as Supremo and BHN-1021 (the hybrid varieties) produced low number of fruits compared to Roma VF (improved variety) and Iwollo local (local variety) that produced small but many fruits. This could be attributed to compensation of fruit size for higher fruit number. It could also be as a result of sink source relationship; more sink competing for limited photosynthate from the source which probably resulted to reduction in fruit size obtained in varieties with high fruit number per plant. Olaniyi et al. (2010) reported that sink size which is genetically controlled influences fruit production in tomato.

Fresh fruit weight per plant varied significantly among the tomato varieties with Supremo variety having superior value over other varieties investigated (Table 4). Varietal influence on the yield of fruits per plant was also reported by Singh and Sahu (1998). Mishra and Lal (1998) also found that variety Pusa-Ruby gave the maximum fruit yield $(2.7 \mathrm{~kg} / \mathrm{plant})$ among the 39 tomato cultivars they investigated. Tomato yield per plant is the product of fruit weight and number of fruits per plant. Supremo variety though with least fruit number had the highest weight of a fresh fruit and outperformed other varieties in terms of fresh fruit weight per plant. This could possibly be attributed to possession of higher stomatal conductance, better partitioning of photosynthetic materials towards economic yield, better genetic structure and higher potential to transport photosynthetic materials within plants. This is similar to the findings of Biswas et al. (2015), Gardner et al. (1990) and Zaki et al. (1999) who attributed the yield differences in crop cultivars to stomatal conductance 
value and to differences in partitioning of photosynthetic materials towards economic yield. It is also in harmony with the findings of Clark et al., (1997) who attributed the differences in yield and its components between crop genotypes to variations in genetic structure, mineral concentration and potentials to transport photosynthetic materials within plants. According to Elings (1999) yield is determined by the interaction between the genetic make-up of a plant and its environment. A cultivar can fulfill its genetic potential for yield and quality only under optimal conditions. The Supremo and BHN-1021 (hybrid varieties) probably exhibited heterozygous vigour. This could possibly explain why they outperformed Roma VF (improved variety) and Iwollo local (local variety) in overall yield per plant. Comparing the different varieties the results revealed that Supremo was generally the best cultivar for cultivation under high tunnel.

\section{Conclusion}

The findings of the study showed that there were significant variations in performance of the four tomato varieties evaluated. Supremo variety produced big fruits and outperformed other varieties in fruit yield per plant. Supremo hybrid tomato variety was best suitable for cultivation under high tunnel. It is therefore recommended for high tunnel production of tomato in Iwollo southeastern, Nigeria.

\section{Conflict of interest statement}

Authors declare that they have no conflict of interest.

\section{References}

Adinde, J. O., Uche, O. J., Anieke, U. J., Ukwuani, C. M., Agu, C. J., Nwankwo, O. G., Ugwuanyi, P. O., 2016. Effect of nipping on growth and yield of green bell pepper (Capsicum annuum L. $c v$ goliath) in Iwollo, south-eastern Nigeria. Int. J. Sci. Nature. 7(2), 423-428.

Alawathugoda, C. J., Dahanayake, N., 2014. Effects of Mycorrhizae as a substitute for inorganic fertilizer on growth and yield of tomato (Lycopersicon esculentum L.) and Soybean (Glycin $\max$ L.) and soil microbial activity. Trop. Agric. Res. Ext. 16(4), 107-112.

Barman, D., Sharma, C.K., Singh, I.P., Sardana, S.D.L.C., 1995. Genetic variability in exotic lines of tomato (Lycopersicon esculentum Mill). Int. J. Trop. Agric. 13, 265-268.

Benton, J., 2008. Tomato Plant Culture: In the Field, Greenhouse, and Home Garden. Taylor \& Francis Group, LLC. Pp.81-86.

Biswas, M., Sarkar, D. R., Asif, M. I., Sikder, R. K, Mehraj H., Jamal Uddin, A. F. M., 2015. Comparison of growth and yield characteristics of BARI tomato varieties. J. Biosci. Agric. Res. 3(1), 01-07.
Blancard, D., 1997. A Colour Atlas of Tomato Diseases: Observations, Identification and Control. John Wiley \& Sons, New York. 212p.

Bok, I., Madisa, M., Machcha, D., Moamogwe, M., More, K., 2006. Manual for vegetable production in Botswana. Department of Agricultural Research, Gaborone, Botswana.

Campbell, N. A., Reece, J. B., Urry, L. A., Cain, M. L., Wasserman, S. A., Minorsky, P. V., Jackson, R. B., 2008. Biology. $8^{\text {th }}$ Edn. Pearson Benjamin Cumming, San Francisco and London. pp.827-830.

Channapagouder, B.B., Biradar, N.R., Bharmagouder, T.D., Rokhade, C.J., 2008. Physiological studies on weed control, efficiency of different herbicides in sunflower. Karnataka J. Agric. Sci. 21(2), 165 -167.

Chaube, H.S., Pundhir, V.S., 2005. Crop Diseases and Their Management. Printice-Hall of India, New Delhi. 703p.

Clark, R.B., Zeto, S.K., Baligar, V.C., Ritchey, K.D., 1997. Growth traits and mineral concentrations of maize hybrids grown on unlimed and limed acid soil. J. Plant Nutr. 20(12), 1773-1795.

Davies, J., Hobson, G. E., 1981. The constituents of tomato fruit - the influence of environment, nutrition and genotype. CRC Crit. Rev. Food Sci. Nutr. 15(3), 205-280.

Elings, A., 1999. Some theory and practice of the participatory variety selection and plant breeding. Retrieved on July 20, 2016 from: http//:www.cdlprogram.org/final/firstphase/ acr_reader/participatory_variety_selection

Enujeke, E.C., 2013. Effects of variety and spacing on growth characters of hybrid maize. Asian J. Agric. Rural Develop. 3(5), 296-310.

Enujeke, E.C., Emuh, F.N., 2015. Evaluation of some growth and yield indices of five varieties of tomato (Lycopersicon esculentum Mill) in Asaba Area of Delta State, Nigeria. Global J. Biosci. Biotechnol. 4(1), 21-26.

FAO, 1979. Recommended practices for the prevention of mycotoxins in food, feed, and their products. Food Agric. Organ. UN Rome, Italy. 51, 35-45.

Fayaz, A., Khan, O., Sarwar, S., Hussain, A., Sher, A., 2007. Performance evaluation of tomato cultivars at high altitude. Sarhad J. Agric. 23(3), 581-585.

Gardner, F.P., Alle, V., McCloud, D.E., 1990. Yield characteristics of ancient roses of maize compared to modern hybrid. Agron. J. 82(5), 864-868.

GenStat Release 10.3DE, 2011. Discovery Edition 4 VSN International Ltd. Rothamsted Experimental Station, Howel, Hempstead, UK.

George, B., Kaur, C., Khurdiya, D. S., Kapoor, H. C., 2004. Antioxidants in tomato (Lycopersium esculentum Mill.) as a function of genotype. Food Chem. 84, 45-51.

Giovanelli, G., Lavelli, V., Peri, C., Nobili, S., 1999. Variation in ripening. J. Sci. Food Agric. 79, 1583-1588.

Giovannucci, E., 1999. Tomatoes, tomato-based products, lycopene and cancer-review of the epidemiologic literature. J. Nat. Cancer Inst. 91(4), 317-331.

Haque, M. M., Rehman, A. K. M., Hossain, S. M. M., 1998. Physiological and yield potential of some promising tomato lines at different planting times. Pak. J. Agric. Res. 9(3), 359362.

Haydar, A., Mandal, M.A., Ahmed, M.B., Hannan, M.M., Karim, R., Razvy, M.A., Roy, U.K., Salahin, M., 2007. Studies on genetic variability and interrelationship among the different traits in tomato. Middle-East J. Sci. Res. 2(3-4), 139-142.

Hulbert, S.H., Webb, C.A., Smith, S.M., Sun, Q., 2001. Resistance gene complexes: Evolution and utilization. Ann. Rev. Phytopathol. 39, 285-312. 
Ibrahim, K. Amans, A., Abubakar, I.U., 2000. Growth indices and yield of Tomato (Lycopesicon esculentum Karest) varieties as influenced by crop spacing at samaru. Proc. 18th HORTSON Conf. 1, 40-47.

Joshi, A., Vikram, A., Thakur, M.C., 2004. Studies on genetic variability, correlation and path analysis for yield and physico-chemical traits in tomato. Prog. Hort. 36(1), 51-58.

Kallo, G., Chaurasia, S. N. G., Major, S., Singh, M., 1998. Stability analysis in tomato. Vegetable Sci. 25(1), 81-84.

Langlois, D., Etievant, P. X., Pierron, P., Jorrot, A., 1996. Sensory and instrumental characterization of commercial tomato varieties. Z Lebensm Unters Forsch, 203, 534-540.

Leonardi, C., Ambrosino, P., Esposito, F., Fogliano. V., 2000. Antioxidant activity and carotenoid and tomatine contents in different typologies of fresh consumption tomatoes. J. Agric. Food Chem. 48, 4723-4727.

Ma, J.H., 1985. Varietal trials on tomato. In: Training Report of the 3rd Regional Training Programme in Vegetable Production and Research. TOPAVRDC, Thailand.

Majambu, I.S., Ogunlella, V.B., Ahmed, M.K., 1996. Responses of Two Okro (Abelmoschus esculentus (L.) Moench.) varieties to fertilizer growth and nutrient concetration as influenced by nitrogen and phosphorusapplications. Fertilizer Res. 8(3), 297-306.

Manoj, R., Raghav, M., 1998. Performance of F1 hybrids and high yielding varieties of tomato under mid-west plains of Uttar Pardesh. Progressive Hort. 30(3), 194-197.

Maplandia, 2016. Iwollo-Oye. Retrieved on July 20, 2016 from:www.maplandia.com/nigeria/enugu/ezeagu/iwollo-oye.

Meher, B. B., Lawande, K. E., Joshi, V. R., 1994. Effect of different varieties and planting seasons in seed yield and yield and quality of tomato. J. Maharashtra Agric. Univ. 19(3), 393-395.

Mesbah, A., Garcia y Garcia, A., Frost, S., 2012. Tomato production inside and outside high tunnel. Field Days Bulletin. pp.143-144.

Mishra, Y. K., Lal, S. D., 1998. Studies on varietal performance of tomato under the agro climatic conditions of U.P. hills. Progressive Hort. 30(3), 153-157.

Mohanty, B.K., 2003. Studies on variability, heritability, interrelationship and path analysis in tomato. Ann. Agric. Res. 23(1), 65-69.

Naika, S., van Lidt de Jeude, J., de Goffau, M., Hilmi, M., van Dam, B., 2005. Cultivation of Tomato: Production, Processing and Marketing. CTA. Series no. 17.

Nzanza, B., 2006. Yield and quality of tomato as influenced by different $\mathrm{Ca}, \mathrm{Mg}, \mathrm{K}$ nutrition. M.Sc. Thesis, University of Pretoria, South Africa.

Obi, I.U., 2002. Statistical Methods of Detecting Differences Between Treatment Means and Research Methodology Issues in Laboratory and Field Experiments Ap. Express Publication Company, Nsukka, Nigeria. 117p.

Olaniyi, J.O., Akanbi, W.B., Adejumo, T.A., Akande, O.G., 2010. Growth, fruit yield and nutritional quality of tomato varieties.
Afr. J. Food Sci. 4(6), 398-402.

Omeje, T.E., Ugwuoke, K.I., Adinde, J.O., Ogwulumba, S. I., Unigwe, L.O., 2016. Effect of cropping season on the control of Taro leaf blight (Phytophthora colocasiae) of cocoyam (Colocasia esculenta L.) in Nsukka, south eastern Nigeria. Int. J. Appl. Biol. Res. 6(1), 30-39.

Opena, R.T., Green, S.K., Talekar, N.S., Chen, J.C., 1989. Genetic improvement of tomato adaptability to the tropics: Progress and future prospects. In: Tomato and Pepper Production in the Tropics (Ed.: Green, S.K.). Asian Vegetable Research and Development Centre (AVRDC), Shanhua, Tainan, Taiwan. pp.70-75.

Sajjan, A.S., Shekhargounda, M., Badanur, 2002. Influence of data of sowing, spacing and levels of nitrogen on yield attributes and seed yield of Okro. Ikamataka. J. Agric. Sci. 15(2), 267-274.

Salunkhe, D. K., Desai, B.B., Bhat, N.R., 1987. Vegetable and Flower Seed Production. $1^{\text {st }}$ Edn. Agricole Pub. Acad., New Delhi, India. 135p.

Schonbeck, M., Damian, K., Dawling, P., Maloney, C., 2006. Tomatoes: Organic production in Virginia. Virginia Association for Biological Farming Information Sheet. No. 506. Retrieved on July 10, 2016 from: http://www. vabf.org/docman/information-sheets/tomatoes -organic

Singh, A.K., Raj, N., 2004. Variability studies in tomato under cold arid condition o Ladakh. Hort. J. 17, 67-72.

Singh, D. N., Sahu, A. A., 1998. Performance of tomato cultivars in winter season on entisol of Orissa. Environ. Ecol. 16(4), 766-762.

Tan, C. S., 2006. Storage conditions for fresh fruit and vegetables. Farmnote No 28/88. Department of Agriculture and Food WA.

Wells, O.S., Loy, J.B., 1993. Row covers and high tunnels enhance crop production in the Northeastern United States. Hort. Technol. 3, 94.

Wittwer, S. H., Castilla, N., 1995. Protected cultivation of horticultural crops worldwide. HortTechnol. 5, 6-23.

Yu, Z.H., Wang, J.F., Stall, R.E., Vallejos, C.C., 1995. Genomic localization of tomato genes that control a hypersensitive reaction to Xanthomonas campestris pv. vesicatoria (Doidge) Dye. Gen. 141, 675-682.

Zahedi, S. M., Ansari, N. A., 2012. Comparison in quantity characters (flowering and fruit set) of ten selected tomato (Solanum lycopersicum L.) genotypes under subtropical climate conditions (Ahvaz). Int. Res. J. Appl. Basic. Sci. 3(6), 1192-1197.

Zaki, N.M., El-Gazar, M.M., El-Din, K.M.G., Ahmed, M.A., 1999. Partition and migration of photosynthates in some maize hybrids. Egypt J. Appl. Sci. 14(6), 117-139.

Žnidarčič, D., Trdan, S., Zlatič, E., 2003. Impact of growing methods on tomato (Lycopersicon esculentum Mill) yield and sensory quality. Zb. Biotech. Fak. Univ. Ljublj. Knet. 81(2), 341-348.

\section{How to cite this article:}

Ugwuanyi, P. O., Nwankwo, O. G., Adinde, J. O., Anieke, U. J., Ukwuani, C. M., Aniakor, A. C., 2016. Evaluation of performance diversity among four determinate tomato (Lycopersicon esculentum Mill.) varieties grown under high tunnel in Iwollo, South Eastern Nigeria. Int. J. Curr. Res. Biosci. Plant Biol. 3(10), 49-56. doi: http://dx.doi.org/10.20546/ijcrbp.2016.310.007 